\title{
FEEDING MANAGEMENT STRATEGY FOR SHEEP IN FEEDLOT IN HOT AND HUMID REGION
}

\author{
ESTRATÉGIA DE MANEJO ALIMENTAR PARA OVINOS CONFINADOS EM \\ REGIÃO QUENTE E ÚMIDA
}

\section{Juana CHAGAS ${ }^{\text {; }}$ Marcelo de Andrade FERREIRA² ${ }^{2}$ Marcílio de AZEVEDO²; Michelle SIQUEIRA $^{3}$; Ághata ELINS ${ }^{4}$; Leonardo BARROS ${ }^{4}$}

1. Doutoranda em Nutrição de Ruminantes, Departamento de Zootecnia, Universidade Federal Rural de Pernambuco - PPGZ-UFRPE, Recife, PE, Brasil. juanachagas@gmail.com; 2. Professor Adjunto, DZO-UFRPE, Recife, PE, Brasil, 3. Mestranda em Nutrição de Ruminante, DZO-UFRPE, Recife, PE, Brasil; 4. Graduando em Zootecnia, bolsista PIBIC/ CNPq - UFRPE, Recife, PE, Brasil.

\begin{abstract}
This study aimed to evaluate the effect of different feeding schedules on the ingestive behavior, dry matter (DM) intake, neutral detergent fiber intake (NDF), respiratory rate (RR) and rectal temperature (RT) of Santa Ines sheep, in feedlot in hot and humid climate region. Five non-castrated male sheep with an initial average weight of 27 $\pm 3 \mathrm{~kg}$ were distributed in a 5x5 Latin Square experimental design. Feed was offered twice daily, the first meal at 7:00h for all treatments, and the second meal, was offered at: 13:30h, 15:00h, 16:30h, 18:00h, or 19:30h. The RR and RT were measured thrice (morning, afternoon and evening) in a day. The feeding behavior (time of eating, rumination and idleness) was recorded in minutes for period of 24 hours visually. The environmental conditions (air temperature and humidity) was measured to determine the thermal comfort index, THI (Temperature-Humidity Index), which ranged between 72 and 83 . There was no evidence that different afternoon feeding times affected rectal temperature during the morning $\left(38.9^{\circ} \mathrm{C}\right)$, afternoon $\left(39.0^{\circ} \mathrm{C}\right)$ or evening $\left(39.0^{\circ} \mathrm{C}\right)$. The respiratory rate during the afternoon was higher for animals fed at $15: 00 \mathrm{~h}$ $\left(55.2 \mathrm{mov} \cdot \mathrm{min}^{-1}\right)$ than for animals fed at $18: 00 \mathrm{~h}$ or $19: 30 \mathrm{~h}\left(29.6\right.$ and $31.6 \mathrm{mov} \cdot \mathrm{min}^{-1}$, respectively).
\end{abstract}

KEYWORDS: Animal handling. Comfort index. Feeding behavior.

\section{INTRODUCTION}

The low animal productivity in the tropics is associated to multiple factors; of these, the adverse weather conditions that narrow the availability of forage, influences the performance of livestock in some regions. The high ambient temperature is the major barrier to animal production, and this effect is aggravated when heat stress is accompanied by high ambient humidity, hampering heat dissipation and promoting thermal stress (PENNINGTON; VAN DEVENDER, 2004; SUNIL KUMAR et al., 2011). Whereas, production efficiency is better when animal do not need to use thermoregulatory mechanisms (SOUZA et al., 2005).

Adapted breeds can also suffer stress arising from adverse weather conditions of the tropics. In elevated environments temperature, in which heat production exceeds dissipation by the animals, all the sources that generate endogenous heat are reduced i.e., mainly feed intake and basal metabolism, while the respiratory rate and surface temperature tend to increase (SOUZA et al., 2007). Therefore, it is recommended to adopt intensive farming systems as feedlot, use of phenotypically heat resistant breeds and adjust feed schedules to avoid stressful situations in order to improve potential herd production (BEEDE; COLLIER, 1986).

The supply time of feeding may affect heat production and thermal equilibrium (BROSH et al., 1998), since feed intake and digestion can increase endogenous heat (WEST, 2003). The heat increase combined with high air temperatures and high relative humidity may result in heat stress for the animal, once the frequency of feeding activity during the hottest hours of the day tends to be reduced (RAY; ROUBICEK, 1971). Weather variables might cause changes in the physiological responses of animals as well as ingestive behavior, so it is necessary to study their effects on animal performance and their interactions with different handling strategies. Studies relating these points associated with a native sheep breed have not been conducted so far.

Given the discussion above, it is speculated that changes in the feeding management, with diet supply at cooler hours of the day, can modify the feeding behavior altering the physiological responses. This study aimed to evaluate the effect of different afternoon feeding schedules on rectal temperature, respiratory rate, dry matter intake, neutral detergent fiber intake and the feeding behavior of Santa Ines sheep in feedlot in hot and humid climate region. 


\section{MATERIAL AND METHODS}

\section{Housing and animals}

The experiment was conducted at the Department of Animal Science at the Universidade Federal Rural de Pernambuco, located in Zona da Mata of the state of Pernambuco, Brazil. The region present tropical climate, hot and humid weather, with heavy annual rainfall during the autumn and winter (KÖPPEN, 1948). The temperature range of 22 to $30^{\circ} \mathrm{C}$, humidity of $80 \%$ and present annually rainfall of $2.200 \mathrm{~mm}$. In addition, the region present altitude of $4 \mathrm{~m}$ and it is located in latitude $08^{\circ} 03^{\prime}$ $14^{\prime \prime} \mathrm{S}$ and longitude $34^{\circ} 52^{\prime} 52^{\prime \prime} \mathrm{W}$.

It was used five male sheep of the Santa Ines breed (naturalized Brazilian breed), with an initial average weight of $27 \pm 3 \mathrm{~kg}$. The sheep were housed in suspended individual cages $(1.2 \times 1.6 \mathrm{~m})$, slatted, fitted with individual bunks and drinkers. The cages were arranged in barn with no walls.

Before start the trial period, the animals were adapted to the barn and environment conditions for 30 days.

\section{Diet and treatments}

The diet consisted of 50\% Tifton 85 grass hay (Cynodon dactylon), chopped $2 \mathrm{~mm}, 15 \%$ soybean meal, $34 \%$ corn meal and $1 \%$ mineral salt and was provided as a total mixed ration twice a day to supply the nutritional requirements of feedlot sheep according to NRC (2007). The nutritional composition of experimental diet was DM - dry matter $(86.70 \%), \mathrm{CP}$ - crude protein $(13.74 \%)$, EE ether extract $(2.75 \%)$, NDF - neutral detergent fiber (39.21\%) and OM - organic matter $(93.02 \%)$.

The diet supply was adjusted daily according to the previous day's intake, allowing 100 $\mathrm{g}$ of orts $/ \mathrm{kg}$ of the total DM offered. For determination of DM and NDF intakes were recorded weights of the offered feed and orts, during the data collection of each period.

Between the $3^{\text {rd }}$ and $7^{\text {th }}$ day of each period, samples of hay, concentrate ingredient and orts, of each animal, were taken daily and frozen; composite samples for each period were taken based on identical amounts of fresh matter. Subsequently, the samples were dried in forced-air oven $\left(55^{\circ} \mathrm{C}\right)$ for $72 \mathrm{~h}$ and ground in a Willey-type mill-using sieve of $1 \mathrm{~mm}$ to chemical analyses. The DM, CP, mineral matter (MM), OM and EE contents were analyzed according AOAC (1990) with procedures in topics: 934.01, 935.11, 942.05, 967.05 and 954.02, respectively. NDF was determined according to the methodologies proposed by Van Soest et al. (1991).
The experimental treatment tested in this study was the timing of the second meal, which was provided at $13: 30 \mathrm{~h}, 15: 00 \mathrm{~h}, 16: 30 \mathrm{~h}, 18: 00 \mathrm{~h}$ or $19: 30 \mathrm{~h}$. For all treatments, the first meal was offered at 7:00h.

To each experimental period, the animals were adapted by ten days and submitted to data collections by seven days, totaling 85 days.

2.3. Environmental monitoring and determination of thermal comfort index.

The environment was monitored hourly for 24 hours with a psychrometer and thermometer extreme temperature. From the climatological data, it was possible to calculate the comfort index, THI (Temperature Humidity Index), using the following equation proposed by Thom (1958):

$\mathrm{THI}=\mathrm{T}_{\mathrm{a}}+0.36 \mathrm{~T}_{\mathrm{dp}}+41.5$

Where: $\mathrm{T}_{\mathrm{a}}$ (Air temperature); $\mathrm{T}_{\mathrm{dp}}$ (Dew point temperature).

\section{Rectal temperature and respiratory rate}

The physiological parameters, respiratory rate $(\mathrm{RR})$ and rectal temperature $(\mathrm{RT})$ were recorded three times in a day: i.e., morning, afternoon and evening (9:00h, 16:00h and 19:30h, respectively). The rectal temperature was measured with a digital clinical thermometer (range of 32 to $42^{\circ} \mathrm{C}$ ). The respiratory rate was obtained by observing the animal flank, counting their breathing movements for 15 seconds, and multiplying the values found by four to obtain the number of respiratory movements per minute (mov. $\mathrm{min}^{-1}$ ) (GOSLING et al., 2014).

\section{Feeding Behavior}

Behavioral observations were conducted visually to measure eating, rumination, and idling activities by the scan sampling method in tenminute intervals, using the methodology proposed by Johnson \& Combs (1991) and adapted for a $24 \mathrm{~h}$ period. The observations started at $6: 00 \mathrm{~h}$ and finished at 6:00h the next day. To evaluate the distribution of each behavioral activity (eating, rumination, and idling), the 24 hours was distributed in two periods: the first period was from $6: 00 \mathrm{~h}$ to 21:00h, subdivided into $90 \mathrm{~min}$ intervals (a total of 15 hours); and the second period was from 21:00h to $6: 00 \mathrm{~h}$, considered in elapsed time (a total of 9 hours). The time was divided according to the feeding activity of the animals, focusing on the period between $6: 00 \mathrm{~h}$ to $21: 00 \mathrm{~h}$. The intervals described above were arranged graphically across 24 hours for each behavioral activity. 


\section{Statistical analyses}

The Latin Square Design $(5 \times 5)$ was applied using five animals, five periods and five treatments (afternoon feeding schedules). The data were subjected to analysis of variance according to the model:

$$
\mathrm{Y}_{\mathrm{ijkl}}=\mu+\mathrm{D}_{\mathrm{i}}+\mathrm{R}_{\mathrm{i}}+\mathrm{A}_{\mathrm{j}}+\mathrm{P}_{\mathrm{k}}+\mathrm{e}_{\mathrm{ijk}}+\varepsilon_{(\mathrm{ijk})}
$$

Where: $Y_{i j k l}=$ response variable measured in the animal $\mathrm{j}$, during the period $\mathrm{k}$, and submitted to the treatment $i ; \mu=$ general constant; $D_{i}=$ fixed effect of treatment $\mathrm{i} ; \mathrm{R}_{\mathrm{i}}=$ residual effect of treatment $\mathrm{i} ; \mathrm{A}_{\mathrm{j}}=$ effect of the animal $\mathrm{j} ; \mathrm{P}_{\mathrm{k}}=$ effect of the experimental period $\mathrm{k} ; \mathrm{e}_{\mathrm{ijk}}=$ random error among experimental plots; and $\varepsilon\left({ }_{\mathrm{ijk}}\right)=$ random error within experimental plots.

The analysis of variance was performed using the PROC GLM of SAS 9.2. The residual effects of treatments were estimated using the CARRY statement. Additionally, the error among experimental plots was calculated using the
LACKOFIT option and it was used to test the direct and residual effects of treatments. It must be emphasized that residual effects of treatments were found to be not significant for any variable, thus they were not presented and discussed. When necessary, direct effects of treatments were compared using SNK's test. All statistical procedures were performed adopting $\alpha=0.05$.

\section{RESULTS}

\section{Environmental parameters and thermal comfort index}

During the trial period, the ranges for the air temperature, relative humidity and THI were 20.4 to $31.9^{\circ} \mathrm{C}, 58.6$ to $100.0 \%$ and 72 to 83 , respectively. To the experimental period, the total precipitation was $53.95 \mathrm{~mm}$. The THI reached the highest values between 11:00 and 15:00h, over 80 (Figure 1).

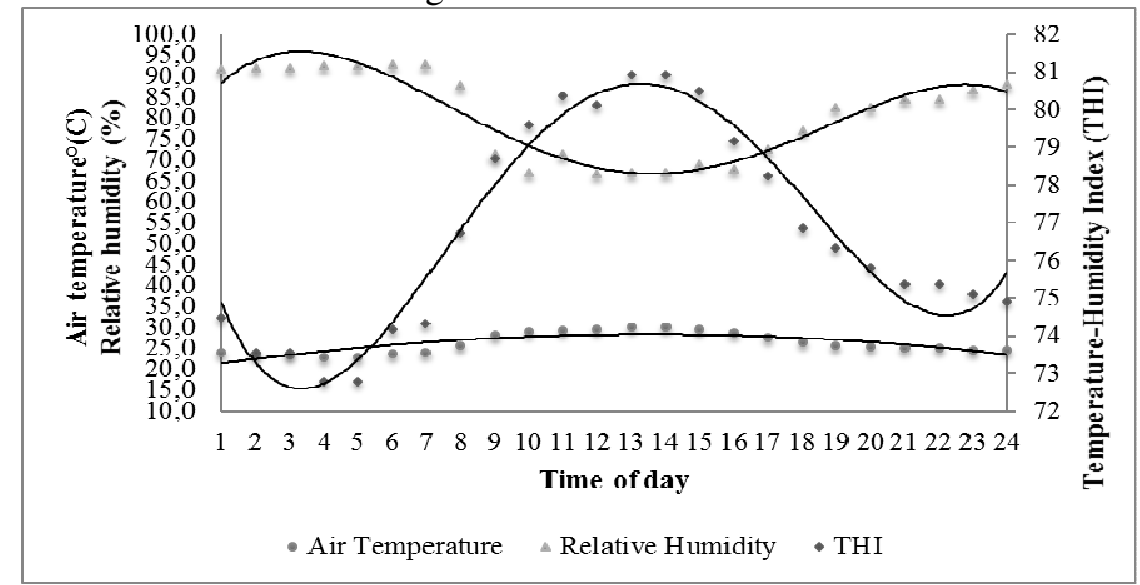

Figure.1. Environment averages during 24 hours.

\section{Rectal temperature and respiratory rate}

Rectal temperatures ranged from 38.5 to $39.6^{\circ} \mathrm{C}$, and different feeding times did not appear to affect this parameter $(\mathrm{P}>0.05)$ (Table 1$)$.

Table 1. Rectal temperature and respiratory rate of sheep submitted to different feeding schedules.

\begin{tabular}{|c|c|c|c|c|c|c|c|}
\hline \multirow[b]{2}{*}{$\begin{array}{c}\text { Periods } \\
\text { of day }\end{array}$} & \multicolumn{5}{|c|}{ Feeding Schedules } & \multirow[b]{2}{*}{$P$} & \multirow[b]{2}{*}{$S E$} \\
\hline & $\begin{array}{c}\mathrm{I} \\
(13: 30 \mathrm{~h})\end{array}$ & $\begin{array}{c}\text { II } \\
(15: 00 \mathrm{~h})\end{array}$ & $\begin{array}{c}\text { III } \\
(16: 30 \mathrm{~h})\end{array}$ & $\begin{array}{c}\text { IV } \\
(18: 00 h)\end{array}$ & $\begin{array}{c}\mathrm{V} \\
(19: 30 \mathrm{~h})\end{array}$ & & \\
\hline & \multicolumn{5}{|c|}{ Rectal temperature } & \multirow[b]{2}{*}{0.26} & \multirow[b]{2}{*}{0.44} \\
\hline Morning & 39.0 & 39.2 & 39.2 & 38.5 & 38.5 & & \\
\hline Afternoon & 39.1 & 39.6 & 39.0 & 39.2 & 38.9 & 0.48 & 0.70 \\
\hline Evening & 38.8 & 39.0 & 39.0 & 39.2 & 38.9 & 0.26 & 0.19 \\
\hline \multicolumn{6}{|c|}{ Respiratory rate } & \multirow{4}{*}{$\begin{array}{l}0.51 \\
0.05 \\
0.28\end{array}$} & \multirow[b]{2}{*}{7.35} \\
\hline Morning & 34.0 & 39.6 & 37.2 & 28.8 & 38.8 & & \\
\hline Afternoon & $40.7_{\mathrm{ab}}$ & $55.2_{\mathrm{a}}$ & $43.0_{\mathrm{ab}}$ & $29.6_{\mathrm{b}}$ & $31.6_{\mathrm{b}}$ & & 8.84 \\
\hline Evening & 32.0 & 36.0 & 35.6 & 34.4 & 29.2 & & 3.69 \\
\hline
\end{tabular}


The respiratory rate ranged from 28.8 to 55.2 mov. min $^{-1}$ (Table 1). The different feeding times did not have effect on the respiratory rates when measured in the morning or evening periods $(\mathrm{P}>0.05)$. However, the respiratory rate was different between the treatments when it was measured in the afternoon, at $16: 00 \mathrm{~h}(\mathrm{P}<0.05)$. The animals that received the second meal at 15:00h had a respiratory rate of $55.2 \mathrm{mov} \cdot \mathrm{min}^{-1}$, which was a faster rate than the animals who received the ration at $18: 00$ or $19: 30 \mathrm{~h}\left(29.6\right.$ and $31.6 \mathrm{mov} \cdot \mathrm{min}^{-1}$, respectively).

\section{Intake and feeding behavior}

DM intake $(1.015 \mathrm{~kg})$ and NDF intake $(0.364 \mathrm{~kg})$ were not influenced by the different afternoon feeding times $(\mathrm{P}>0.05)$. The time spent eating (289.2 $\mathrm{min} /$ day), ruminating (500.4 $\mathrm{min} /$ day), and idling (650.4 $\mathrm{min} /$ day) was also not influenced by the afternoon feeding times (Table 2 ).

Table 2. Dry matter intake (DMI), NDF intake (NDFI), eating time, rumination time and idling time of sheep submitted to different feeding schedules.

\begin{tabular}{|c|c|c|c|c|c|c|c|}
\hline \multirow[b]{2}{*}{ Item } & \multicolumn{5}{|c|}{ Feeding Schedules } & \multirow[b]{2}{*}{$P$} & \multirow[b]{2}{*}{$S E$} \\
\hline & $\begin{array}{c}\text { I } \\
(13: 30 h)\end{array}$ & $\begin{array}{c}\text { II } \\
(15: 00 h)\end{array}$ & $\begin{array}{c}\text { III } \\
(16: 30 h)\end{array}$ & $\begin{array}{c}\text { IV } \\
(18: 00 h)\end{array}$ & $\begin{array}{c}\mathrm{V} \\
(19: 30 \mathrm{~h})\end{array}$ & & \\
\hline $\mathrm{DMI}^{1}$ & 0.981 & 1.083 & 1.053 & 0.995 & 0.966 & 0.28 & 0.06 \\
\hline $\mathrm{NDFI}^{1}$ & 0.359 & 0.393 & 0.371 & 0.350 & 0.347 & 0.23 & 0.02 \\
\hline Eating $^{2}$ & 272 & 304 & 298 & 300 & 272 & 0.59 & 28.8 \\
\hline Rumination $^{2}$ & 566 & 566 & 500 & 434 & 436 & 0.10 & 64.7 \\
\hline Idling2 & 602 & 570 & 642 & 706 & 732 & 0.20 & 79.76 \\
\hline
\end{tabular}

${ }^{1}(\mathrm{Kg} / \mathrm{day}) ;{ }^{2}(\mathrm{~min} / \mathrm{day}) . \mathrm{P}-$ Value; SE - Standard Error.

Distribution of sheep behavioral activities throughout the day

Between 7:30 and 9:00h, all animals had higher intake activity (Figure 2a); however, the animals that received the second meal at 18:00 or 19:30h spent less time feeding than animals fed at 15:00h $(\mathrm{P}<0.05)$ with feeding times of 40,42 and 72 minutes, respectively (Table 3 ).

Table 3. Eating activity over different time intervals (min) during 24 hours for sheep submitted to different feeding schedules.

\begin{tabular}{|c|c|c|c|c|c|c|c|}
\hline \multirow[b]{2}{*}{ Periods of day } & \multicolumn{5}{|c|}{ Feeding Schedules } & \multirow[b]{2}{*}{$P$} & \multirow[b]{2}{*}{$S E$} \\
\hline & $\begin{array}{c}\text { I } \\
(13: 30 \mathrm{~h})\end{array}$ & $\begin{array}{c}\text { II } \\
(15: 00 \mathrm{~h})\end{array}$ & $\begin{array}{c}\text { III } \\
(16: 30 \mathrm{~h})\end{array}$ & $\begin{array}{c}\text { IV } \\
(18: 00 \mathrm{~h})\end{array}$ & $\begin{array}{c}\mathrm{V} \\
(19: 30 \mathrm{~h})\end{array}$ & & \\
\hline 06:00-07:30 & $26_{\mathrm{BC}}$ & $26_{\mathrm{BC}}$ & $24_{C}$ & 22 & $26_{\mathrm{AB}}$ & 0.21 & 2.12 \\
\hline 07:30-09:00 & $58_{\mathrm{abA}}$ & $72_{\mathrm{aA}}$ & $60_{\mathrm{abAB}}$ & $42_{b}$ & $40_{\mathrm{bAB}}$ & 0.04 & 10.90 \\
\hline 09:00-10:30 & $16_{\mathrm{BC}}$ & $14_{\mathrm{C}}$ & $18_{\mathrm{C}}$ & 18 & $14_{\mathrm{AB}}$ & 0.98 & 9.30 \\
\hline $10: 30-12: 00$ & $10_{\mathrm{C}}$ & $14_{\mathrm{C}}$ & $10_{\mathrm{C}}$ & 12 & $10_{\mathrm{B}}$ & 0.96 & 9.02 \\
\hline $12: 00-13: 30$ & $8_{\mathrm{C}}$ & $8_{C}$ & $8_{C}$ & 24 & $12_{\mathrm{AB}}$ & 0.65 & 13.56 \\
\hline $13: 30-15: 00$ & $46_{\mathrm{AB}}$ & $14_{\mathrm{C}}$ & $10_{\mathrm{C}}$ & 14 & $26_{\mathrm{AB}}$ & 0.08 & 13.86 \\
\hline $15: 00-16: 30$ & $24_{\mathrm{bBC}}$ & $54_{\mathrm{aAB}}$ & $24_{\mathrm{bC}}$ & $28_{\mathrm{b}}$ & $18_{\mathrm{bAB}}$ & 0.01 & 9.40 \\
\hline $16: 30-18: 00$ & $14_{\mathrm{bBC}}$ & $26_{\mathrm{bBC}}$ & $70_{\mathrm{aA}}$ & $24_{b}$ & $26_{\mathrm{bAB}}$ & 0.00 & 13.02 \\
\hline 18:00-19:30 & $28_{\mathrm{bBC}}$ & $22_{\mathrm{bC}}$ & $26_{\mathrm{bC}}$ & $54 a$ & $12_{\mathrm{bAB}}$ & 0.00 & 7.92 \\
\hline 19:30-21:00 & $14_{\mathrm{bBC}}$ & $16_{\mathrm{bC}}$ & $88_{\mathrm{bC}}$ & $24_{b}$ & $54_{\mathrm{aA}}$ & 0.01 & 11.09 \\
\hline 21:00-06:00 & $28_{\mathrm{BC}}$ & $36_{\mathrm{BC}}$ & $40_{\mathrm{BC}}$ & 40 & $32_{\mathrm{AB}}$ & 0.92 & 16.77 \\
\hline$P$ & 0.0007 & $<0.0001$ & $<0.0001$ & 0.06 & 0.05 & - & - \\
\hline$S E$ & 15.51 & 15.72 & 16.71 & 16.71 & 18.95 & - & - \\
\hline
\end{tabular}

Means followed by lowercase letters in the same row differ by the SNK test at 5\% probability. Means followed by capital letters in the same column differ by the SNK test at 5\% probability. . P -- Value; SE - Standard Error. 
For all animals, peak time of ingestion was observed at intervals of the day when the diet was supplied (Figure 2a), even though there was variation in the time spent for each treatment (Table $3)$. The animals that received the second meal at 13:30h, 18:00h or 19:30h showed greater feeding activity during other time intervals, specifically during the intervals $18: 00 \mathrm{~h}$ to $19: 30 \mathrm{~h}, 12: 00 \mathrm{~h}$ to $13: 30 \mathrm{~h}$ and $13: 30 \mathrm{~h}$ to $15: 00 \mathrm{~h}$, respectively. Low feeding rates were also observed during the $21: 00 \mathrm{~h}$ to 6:00h time range for all animals.
CHAGAS, J. et al

The distribution of rumination time for the animals during the different time intervals is shown in Figure 2b. The greatest amount of time spent on this activity occurred between 21:00h and 6:00h.

The rumination activity varied between 10:30h and 12:00h (Table 4). When the afternoon ration was provided at $13: 30 \mathrm{~h}$ or $15: 00 \mathrm{~h}$, the animals spent more time between $10: 30 \mathrm{~h}$ and $12: 00 \mathrm{~h}$ ruminating ( 52 and 50 minutes, respectively) compared to the animals that had their rations supplied at 18:00h or 19:30h (22 and 24 minutes, respectively) $(\mathrm{P}<0.05)$.

Table 4. Rumination activity over different time intervals (min) during 24 hours for sheep submitted to different feeding schedules.

\begin{tabular}{cccccccc}
\hline & \multicolumn{7}{c}{ Feeding Schedules } \\
\cline { 2 - 7 } Periods of day & $\begin{array}{c}\mathrm{I} \\
(13: 30 \mathrm{~h})\end{array}$ & $\begin{array}{c}\mathrm{II} \\
(15: 00 \mathrm{~h})\end{array}$ & $\begin{array}{c}\text { III } \\
(16: 30 \mathrm{~h})\end{array}$ & $\begin{array}{c}\text { IV } \\
(18: 00 \mathrm{~h})\end{array}$ & $\begin{array}{c}\mathrm{V} \\
(19: 30 \mathrm{~h})\end{array}$ & $P$ & $S E$ \\
\hline $06: 00-07: 30$ & $26_{\mathrm{BC}}$ & $24_{\mathrm{B}}$ & $24_{\mathrm{B}}$ & $8_{\mathrm{B}}$ & $14_{\mathrm{B}}$ & 0.274 & 10.02 \\
$07: 30-09: 00$ & $24_{\mathrm{BC}}$ & $6_{\mathrm{B}}$ & $2_{\mathrm{B}}$ & $2_{\mathrm{B}}$ & $16_{\mathrm{B}}$ & 0.362 & 13.74 \\
$09: 00-10: 30$ & $62_{\mathrm{B}}$ & $50_{\mathrm{B}}$ & $30_{\mathrm{B}}$ & $20_{\mathrm{B}}$ & $38_{\mathrm{B}}$ & 0.060 & 15.07 \\
$10: 30-12: 00$ & $52_{\mathrm{aBC}}$ & $50_{\mathrm{aB}}$ & $42_{\mathrm{abB}}$ & $22_{\mathrm{bB}}$ & $24_{\mathrm{bB}}$ & 0.010 & 10.28 \\
$12: 00-13: 30$ & $26_{\mathrm{BC}}$ & $28_{\mathrm{B}}$ & $22_{\mathrm{B}}$ & $28_{\mathrm{B}}$ & $36_{\mathrm{B}}$ & 0.836 & 13.27 \\
$13: 30-15: 00$ & $12_{\mathrm{C}}$ & $34_{\mathrm{B}}$ & $40_{\mathrm{B}}$ & $28_{\mathrm{B}}$ & $12_{\mathrm{B}}$ & 0.13 & 13.43 \\
$15: 00-16: 30$ & $32_{\mathrm{BC}}$ & $8_{\mathrm{B}}$ & $22_{\mathrm{B}}$ & $20_{\mathrm{B}}$ & $14_{\mathrm{B}}$ & 0.41 & 13.43 \\
$16: 30-18: 00$ & $42_{\mathrm{BC}}$ & $14_{\mathrm{B}}$ & $8_{\mathrm{B}}$ & $34_{\mathrm{B}}$ & $28_{\mathrm{B}}$ & 0.33 & 19.26 \\
$18: 00-19: 30$ & $28_{\mathrm{BC}}$ & $28_{\mathrm{B}}$ & $18_{\mathrm{B}}$ & $16_{\mathrm{B}}$ & $14_{\mathrm{B}}$ & 0.58 & 12.12 \\
$19: 30-21: 00$ & $20_{\mathrm{B}}$ & $28_{\mathrm{B}}$ & $34_{\mathrm{B}}$ & $22_{\mathrm{bB}}$ & $4_{\mathrm{B}}$ & 0.32 & 15.29 \\
$21: 00-06: 00$ & $244_{\mathrm{A}}$ & $302_{\mathrm{A}}$ & $262_{\mathrm{A}}$ & $298_{\mathrm{A}}$ & $224_{\mathrm{A}}$ & 0.26 & 42.58 \\
\hline$P$ & $<0.001$ & $<0.001$ & $<0.001$ & $<0.001$ & $<0.001$ & - & - \\
$S E$ & 18.95 & 27.46 & 29.72 & 25.15 & 35.80 & - & - \\
\hline
\end{tabular}

Means followed by lowercase letters in the same row differ by the SNK test at 5\% probability. Means followed by capital letters in the same column differ by the SNK test at $5 \%$ probability. P - Value; SE - Standard Error.

The animals spent time at idle throughout the day, in short intervals between the activities of feeding and rumination (Figure 2c). Between 6:00h and $21: 00 \mathrm{~h}$, this activity varied over time by the animals in a random pattern, and idling time was more relevant between the hours of 21:00h and 6:00h.

The time spent by the animals in idle activity differed during the $9: 00 \mathrm{~h}$ to $10: 30 \mathrm{~h}$ range.
The animals that received the second meal at 18:00h spent more time idle than the animals that received the second meal at 13:30h (Table 5). In the afternoon, between $16: 30 \mathrm{~h}$ and $18: 00 \mathrm{~h}$, the animals who received the second meal at $16: 30 \mathrm{~h}$ had an idle time equal to that of the animals whose feeding time was $13: 30 \mathrm{~h}$.

Table 5. Idling activity over different time intervals (min) during 24 hours for sheep submitted to different feeding schedules.

\begin{tabular}{cccccccc}
\hline & \multicolumn{9}{c}{ Feeding Schedules } & & \\
\cline { 2 - 6 } Periods of day & I & II & III & IV & V & \multirow{2}{*}{$P$} & \multirow{2}{*}{$S E$} \\
& $(13: 30 \mathrm{~h})$ & $(15: 00 \mathrm{~h})$ & $(16: 30 \mathrm{~h})$ & $(18: 00 \mathrm{~h})$ & $(19: 30 \mathrm{~h})$ & & \\
\hline $06: 00-07: 30$ & $38_{\mathrm{BCD}}$ & $40_{\mathrm{B}}$ & $44_{\mathrm{B}}$ & $54_{\mathrm{B}}$ & $50_{\mathrm{B}}$ & 0.52 & 11.30 \\
$07: 30-09: 00$ & $8_{\mathrm{D}}$ & $12_{\mathrm{B}}$ & $28_{\mathrm{B}}$ & $46_{\mathrm{B}}$ & $34_{\mathrm{B}}$ & 0.08 & 14.65
\end{tabular}


Feeding management...

CHAGAS, J. et al

\begin{tabular}{cccccccc}
$09: 00-10: 30$ & $12_{\mathrm{bCD}}$ & $26_{\mathrm{abB}}$ & $42_{\mathrm{abB}}$ & $56_{\mathrm{aB}}$ & $34_{\mathrm{abB}}$ & 0.03 & 13.15 \\
$10: 30-12: 00$ & $28_{\mathrm{BCD}}$ & $26_{\mathrm{B}}$ & $36_{\mathrm{B}}$ & $56_{\mathrm{B}}$ & $58_{\mathrm{B}}$ & 0.04 & 12.70 \\
$12: 00-13: 30$ & $54_{\mathrm{BC}}$ & $54_{\mathrm{B}}$ & $60_{\mathrm{B}}$ & $44_{\mathrm{B}}$ & $42_{\mathrm{B}}$ & 0.77 & 17.56 \\
$13: 30-15: 00$ & $32_{\mathrm{BCD}}$ & $42_{\mathrm{B}}$ & $40_{\mathrm{B}}$ & $40_{\mathrm{B}}$ & $52_{\mathrm{B}}$ & 0.58 & 12.89 \\
$15: 00-16: 30$ & $34_{\mathrm{BCD}}$ & $28_{\mathrm{B}}$ & $44_{\mathrm{B}}$ & $3_{\mathrm{B}}$ & $58_{\mathrm{B}}$ & 0.22 & 13.69 \\
$16: 30-18: 00$ & $38_{\mathrm{abBCD}}$ & $50_{\mathrm{aB}}$ & $12_{\mathrm{bB}}$ & $50_{\mathrm{aB}}$ & $36_{\mathrm{aB}}$ & 0.02 & 11.65 \\
$18: 00-19: 30$ & $32_{\mathrm{BCD}}$ & $42_{\mathrm{B}}$ & $48_{\mathrm{B}}$ & $24_{\mathrm{B}}$ & $62_{\mathrm{B}}$ & 0.10 & 14.32 \\
$19: 30-21: 00$ & $60_{\mathrm{B}}$ & $44_{\mathrm{B}}$ & $52_{\mathrm{B}}$ & $48_{\mathrm{B}}$ & $28_{\mathrm{B}}$ & 0.40 & 17.44 \\
$21: 00-06: 00$ & $262_{\mathrm{A}}$ & $202_{\mathrm{A}}$ & $232_{\mathrm{A}}$ & $244_{\mathrm{A}}$ & $278_{\mathrm{A}}$ & 0.16 & 31.98 \\
\hline$P$ & $<0.001$ & $<0.001$ & $<0.001$ & $<0.001$ & $<0.001$ & - & - \\
$S E$ & 21.18 & 24.89 & 27.91 & 25.15 & 35.81 & - & - \\
\hline
\end{tabular}

Means followed by lowercase letters in the same row differ by the SNK test at 5\% probability. Means followed by capital letters in the same column differ by the SNK test at 5\% probability. P - Value; SE - Standard Error.

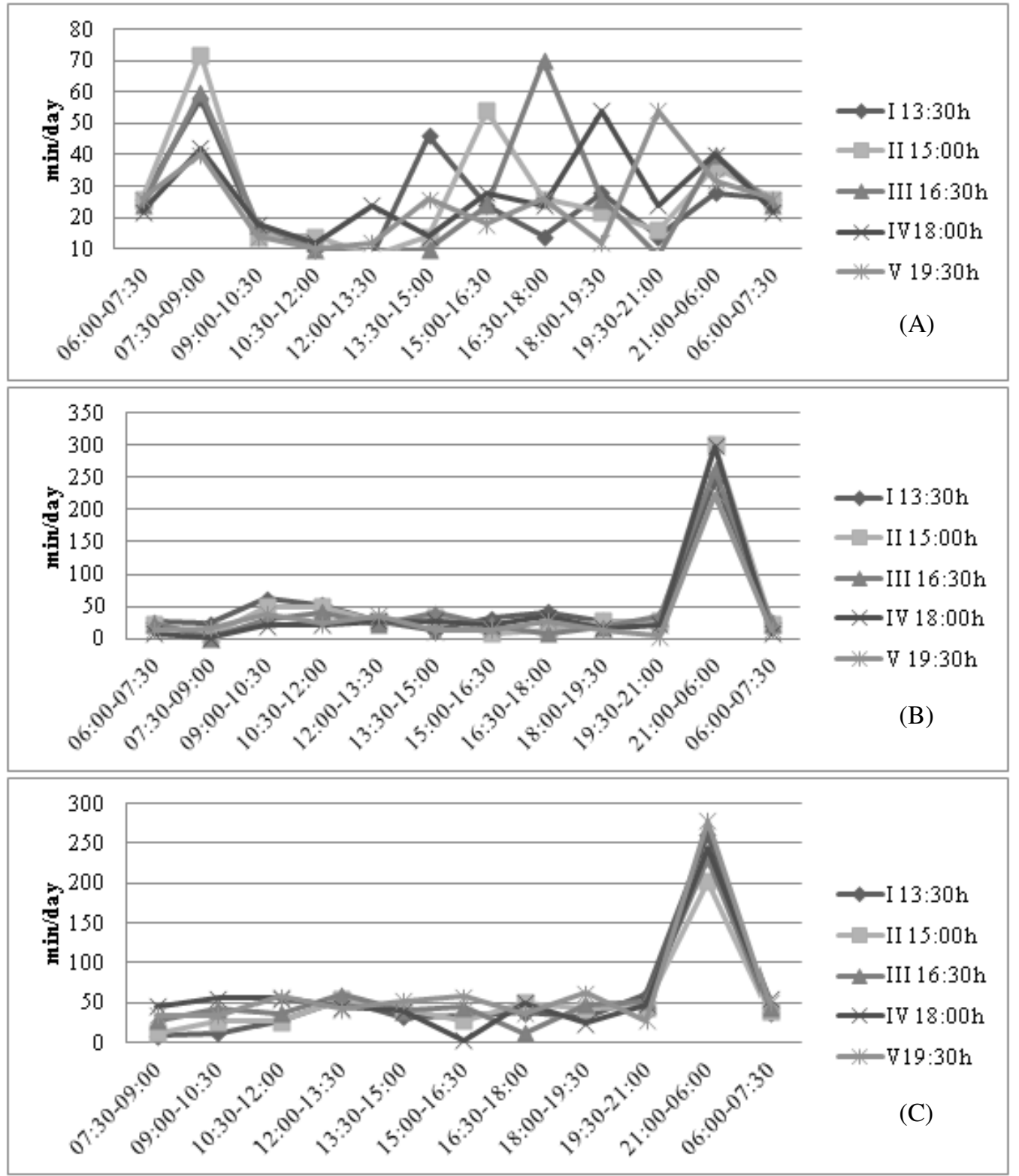

Figure 2. Ingestive behavior of sheep in feedlot. (A) Eating activity during 24 h; (B) Rumination activity during $24 \mathrm{~h}$; (C) Idling activity during $24 \mathrm{~h}$. 


\section{DISCUSSION}

\section{Thermal comfort index}

The greatest THI measured during the trial period was 83 (Figure 1), which exceeded the critical THI value of 80 , as estimated (based on rectal temperature) according Neves et al. (2009) in a field study with Santa Ines sheep conducted in the Agreste region of Pernambuco state. Silanikove (2000) deduced that THI values above 78 might cause severe discomfort to maintain normal body temperature in animals. According to the authors, it can be suggested that animals could have presented acute heat stress between 11:00h and 15:00h (Figure 1), since that was considered the most stressful period, throughout the trial.

\section{Rectal temperature and respiratory rate}

The normal physiological range of rectal temperature for sheep is between $38.3^{\circ} \mathrm{C}$ and $39.9^{\circ} \mathrm{C}$ (ROBERTSHAW, 2006) and is considered a symptom of heat stress (BROWN-BRANDL et al., 2006), along with the temperature rate. Rectal temperatures varied in this study between $38.5^{\circ} \mathrm{C}$ and $39.6^{\circ} \mathrm{C}$, which is within the normal range. There was no clear evidence that the different feeding schedule for the second meal influenced rectal temperatures $(\mathrm{P}>0.05)$ (Table 1$)$.

The respiratory rate for sheep under normal physiological conditions can range from 16 to 34 mov. min $^{-1}$ (GAUGHAN et al., 2002). Respiratory movements can quantify heat stress severity, with respiratory rates of $40-60, \quad 60-80$ or $80-120$ mov. in $^{-1}$ indicating low, medium-high and high stress, respectively, for ruminants (SILANIKOVE, 2000). The respiratory rates found in the afternoon for the animals fed at 13:30h, 15:00h and 16:30h (Table 1) were within the range that indicates low stress (40-60 mov. $\mathrm{min}^{-1}$ ). For the animals fed at other time points, the rates measured were not in a range that indicated stress. The respiratory rates measured for all animals in the morning and evening indicated the absence of stress. It was observed that different feeding times influenced the respiratory rate in the afternoon. The animals fed at 15:00h had an increased respiratory rate relative to those animals that were fed at $18: 00 \mathrm{~h}$ and $19: 30 \mathrm{~h}$. The animals fed at 15:00h received their ration one hour before the physiological parameters were evaluated in the afternoon (16:00h). Since ruminal fermentation of soluble carbohydrates promotes increased metabolic activity in the hours following feed intake (YOKOYAMA; JOHNSON, 1993), there was an increase in body temperature, making it necessary for the animals to dissipate excess heat through the airway.

McDowell (1989) reports that accelerated breathing for several hours can interfere with feed intake and rumination and may affect animal performance. However, even for the animals fed at 15:00h, with the highest measured respiratory rate in the afternoon (Table 1), no significant difference was observed with respect to the amount of feed intake or total eating time as compared to the other feeding times (Table 2).

Thus, it was understood that the sheep presented only acute stress (without any apparent symptoms) when exposed to THI above 80; this scenario probably was associated to adaptive capacity of Santa Ines sheep breed and/or the confinement conditions. The results corroborate with Aggarwal and Upadhyay (2012) that suggested initial reactions of the animal to acute heat stress are related more to the behavior (emotional) than thermoregulatory mechanisms.

\section{Intake and feeding behaviors}

The period between 11:00h and 15:00h was considered the most stressful for the animals (Figure 1 ), and within that time period, a second meal was provided at two different times: i.e., 13:30h and 15:00h. It was expected that the animals fed during those two schedules would have less dry matter intake and would have reduced eating and rumination times as well as increased idle time. Dry matter intake decreases under moderate heat stress, a result of decreased time spent eating and a concurrent increase in idle time (COLLIER; COLLIER, 2012), nonetheless, sheep performed equally opposite, thus demonstrating the ability of acclimatization of sheep breed Santa Ines.

Rumination time is influenced by the nature of the diet, particular size, density (TEIMOURI YANSAR et al., 2004) and it seems to be proportional to the cell wall composition of forage (VAN SOEST, 1994). The level of NDF intake was the same for all treatments. It is assumed that that feed ingredients were not selectively consumed by the animals; for these reasons, there were no differences between DM intake, NDF intake and the ingestion or the rumination time $(\mathrm{P}>0.05)$ observed.

\section{Distribution of behavioral activities throughout the day}

The animals were stimulated to feed from the moment in which meals were offered regardless of the different feeding schedules (Figure 2a), which is in agreement to early work (DEVRIES; VON KEYSERLINGK, 2009) who reported that more 
accentuated peaks in feeding activity occur around the time of feed delivery.

The animals fed at 18:00h and 19:30h spent less time eating between $7: 30 \mathrm{~h}$ and 9:00h, most likely because they were in a range of ten hours between the first and the second meal. To adjust the intake, these animals presented a relevant eating during other intervals of the day (Table 3 ). The peak intake activity for the animals fed at $13: 30 \mathrm{~h}$ was during the period between 12:00h and 13:30h, as shown in Figure 2a, whereas the same peak intake activity was observed between 13:30h and 15:00h for animals fed at 19:30h (Figure 2a).

It was observed that the animals fed at 13:30h adjusted their intake because of the long number of hours between the second meal and the first meal of following day (Table 3). Between 13:30h and 15:00h, these animals were encouraged to consume from the provided ration (Figure 2a); however, the time spent on this activity did not significantly differ compared to the other animals ( $P>0.05)$, probably it may be due to amount of time for this activity relative to other treatment ranges during the day.

During the night (between 21:00h and 6:00h), independent of the different afternoon feeding times, ruminants are in the habit of intense rumination (ALBRIGHT et al., 1993). Rumination and idle activities were distributed during the 6:00h to 21:00h period, providing space between feeding events (Figures $2 \mathrm{~b}$ and $2 \mathrm{c}$ ). The time spent on feeding activity was interspersed with one or more periods of rumination or idleness (FISCHER et al., 1998).

Between 10:30h and 12:00h, less time spent on rumination for the animals fed at 18:00h and 19:30h. It was, most likely due to the shorter feeding time during the 7:30h and 9:00h period (Table 3). The differences found for the distribution of idleness between the range of the day and the animals (Table 5) occurred as result of time spent eating and ruminating. Regardless of the afternoon feeding schedule, between 21:00h and 6:00h, the animals showed no difference between time spent no rumination or idle activities (Tables 4 and 5). This result corroborates with Church (1993) that considered rumination activity to be a rest activity that occurs late at night and during the dawn and found that rumination is a difficult behavioral pattern to modify.

\section{CONCLUSIONS}

The animal ingestive behavior is subject to change according to the feeding management since the animals had ingestive peak stimulated by the supply of the diet.

The different supply diet timetables altered respiratory rate, but it did not provide effect on DM intake and the other nutrients. Thus, it is suggested more specific studies, such as performance trial, to identify how those adapting physiologic mechanisms can affect weight gain and animal growth.

RESUMO: O estudo objetivou avaliar o efeito dos diferentes horários de fornecimento da dieta sob parâmetros fisiológicos e comportamento ingestivo de ovinos, confinados em região quente e úmida. Foram utilizados cinco machos de peso médio inicial $(27 \pm 3 \mathrm{~kg}$ ), distribuídos em Quadrado Latino 5 x 5 . O alimento foi ofertado duas vezes ao dia, a primeira refeição às 7:00h e a segunda refeição (tratamentos) foi ofertada às: 13:30h, 15:00h, 16:30h, 18:00h, ou 19:30h. A frequência respiratória (FR) e a temperatura retal (TR) foram avaliadas em 3 períodos do dia. O comportamento ingestivo (tempo de alimentação, ruminação e ócio) foi avaliado visualmente a cada 10 min durante 24 horas. As condições ambientais foram monitoradas para determinar do ITU (índice de temperatura e umidade) que variou entre 72 a 83 . Os animais mantiveram a TR dentro da faixa fisiológica normal e não diferiram dentre os tratamentos experimentais: manhã $\left(38,9^{\circ} \mathrm{C}\right)$, tarde $\left(39,0^{\circ} \mathrm{C}\right)$ e noite $\left(39,0^{\circ}\right)$. A FR também não foi diferente dentre os tratamentos para os períodos da manhã $\left(37,2\right.$ mov. $\left.\mathrm{min}^{-1}\right)$ e noite $\left(34,4\right.$ mov. $\left.\mathrm{min}^{-1}\right)$, porém no período da tarde a FR dos animais alimentados às 15:00h $(55,2$ mov. $\mathrm{min}^{-1}$ ) foi maior do que os demais tratamentos. Os diferentes manejos adotados não exerceram influência sobre os consumos de consumos de matéria seca $(1,015 \mathrm{Kg})$ e FDN $(0,364 \mathrm{Kg})$. Para os tempos totais das atividades de alimentação (289 $\mathrm{min} /$ dia), ruminação (500 min/dia) e ócio (650 min/dia) não foram observadas diferenças em função dos horários de fornecimento da dieta, no entanto houve diferença na distribuição dessas atividades ao longo do dia, em que claramente se observou a adaptação dos animais ao manejo alimentar adotado em cada tratamento experimental. Sugere-se mais estudos específicos a fim de avaliar as interações entre as respostas apresentadas e o desempenho animal.

PALAVRAS-CHAVE: Manejo Animal. Comportamento Ingestivo. Índice de Conforto Térmico 


\section{REFERENCES}

AGgARWAL, A.; UPADHYAY, R. Heat Stress and Animal Productivity. Haryana: Spring India, 2012. 206 p.

ALBRIGHT, J. L. Nutrition, feeding and calves. Feeding behavior of dairy cattle. Journal of Dairy Science. South Oak, v. 76, n. 2, p. 485-498, fev. 1993.

AOAC. Official Methods of Analysis (Sections: 934.01, 935.11, 942.05, 967.05 and 954.02). 15. ed.

Arlington: AOAC, 1990. $1105 \mathrm{p}$.

BEEDE, D. K; COLLIER, R. J. Potential nutritional strategies for intensively managed cattle during thermal stress. Journal of Animal Science. Champaign, v. 62, p. 543-554, out. 1986.

BROWN-BRANDL, T. M.; EIGENBERG, R. A.; NIENABER, J. A. Heat stress risk factors for feedlot heifers. Livestock Science. Amsterdam, v. 105, p. 57-68, abr. 2006. http://dx.doi.org/10.1016/j.livsci.2006.04.025

BROSH, A.; AHARONI, Y.; DEGEN, A. A.; YOUNG, B. A. Effects of solar radiation, dietary energy, and time of feeding on thermoregulatory responses and energy balance in cattle in a hot environment. Journal of Animal Science. Champaign, v. 76, p. 2671-2677, out. 1998.

CHURCH, D. C. The ruminant animal: Digestive physiology and nutrition. 4. ed. New York: O\&B Books, 1993, $641 \mathrm{p}$.

COLLIER, R. J.; COLLIER, J. L. Environmental Physiology of Livestock. Oxford: Wiley-Blackwell, 2012, 300 p. http://dx.doi.org/10.1002/9781119949091

DEVRIES, T. J.; M. A. G.; KEYSERLINGK V.; BEAUCHEMIN, K. A. Understanding Feeding Behavior to Maximize the Potential of Dairy Rations. In: MID-SOUTH RUMINANT NUTRITION CONFERENCE, 2009, Texas. Anais... 2009. p. 23-30.

FISCHER, V.; DESWYSEN, A. G.; DÈPRES, L. DUTILLEUL, P.; LOBATO, J. F. P. Padrões nectemerais do comportamento ingestivo de ovinos. Revista Brasileira de Zootecnia. Brasília, v. 27, p. 362-369, mar. 1998.

GAUGHAN, J. B.; MADER, T. L.; HOLT, S. M. HAHN, L.; YOUNG, B. Review of current assessment of cattle and microclimate during periods of high heat load. Animal Production in Australia. Queensland, v. 24, p. 77-80, jul. 2002.

JOHNSON, T. R.; COMB S, D. K. Effects of prepartum diet, inert rumen bulk, and dietary polythylene glicol on dry matter intake of lactating dairy cows. Journal of Dairy Science. South Oak, v. 74, p. 933-944, mar, 1991.

GOSLING, S. N.; BRYCE, E. K.; GABRIEL, K. M. A.; GOSLING, E. Y.; HANES, J.; ET AL. A glossary for biometeorology. International Journal of Biometeorology. Kent, v. 58, p. 277-308, ago. 2014.

KÖPPEN, W. Climatologia: con un estudio de los climas de la tierra. Buenos Aires: Fondo de Cultura Economica, 1948. 479 p.

MCDOWELL, R. E. Bases biológicas de la producción animal en zonas tropicales. São Paulo: Icone, 1989. $183 \mathrm{p}$.

NATIONAL RESEARCH COUNCIL - NRC. Nutrient Requeriments of Small Ruminants. 1. ed. Washington, DC, USA: National Academy Press, 2007, 362p. 
NEVES, L. M. W.; AZEVEDO, M.; COSTA, L. A. B; GUIM, A.; LEITE, A. M.; CHAGAS, J. C. C. Níveis críticos do índice de conforto térmico para ovinos da raça Santa Inês criados a pasto no agreste do Estado de Pernambuco. Acta Scientiarum Animal Sciences. Maringá, v. 31, n. 2, p. 169-175, mai. 2009.

PENNINGTON, J. A.; VAN DEVENDER, K. Heat stress in dairy cattle. UACES Publications. 2004.

RAY, D. E.; ROUBICEK, C.B. Behavioral of feedlot cattle during two seasons. Journal of Animal Science. Champaign, v. 33, p. 72-76, jul. 1971.

ROBERTSHAW, D. Mechanisms for the control of respiratory evaporative heat loss in panting animals. Journal of Applied Physiology. London, v. 101, p. 664-668. 2006.

http://dx.doi.org/10.1152/japplphysiol.01380.2005

SILANIKOVE, N. Effects of heat stress on the welfare of extensively managed domestic ruminants. Livestock Production Science. Amsterdam, v, 67, p. 1-18, dez, 2000.

SOUZA, E. D.; SOUZA, B. B.; SOUZA, W. H. Determinação dos parâmetros fisiológicos e gradiente térmico de diferentes grupos genéticos de caprinos no Semi-Árido. Revista Ciência e Agrotecnologia. Lavras, v. 29, p. 177-184, feb. 2005.

SOUZA, B. B.; SILVA, R. M. N.; MARINHO, M. L. SILVA, A. G.; SILVA, E. M. N.; SOUZA, A. P. Parâmetros fisiológicos e índice de tolerância ao calor de bovinos da raça Sindi no Semi- árido paraibano. Revista Ciência e Agrotecnologia. Lavras, v. 31, p. 883-888, jun. 2007.

SUNIL KUMAR B. V.; KUMAR A.; MEENA K. Effect of heat stress in tropical livestock and different strategies for its amelioration. Journal of Stress Physiology \& Biochemistry. London, v. 7, n. 1, p. 45-54, jan, 2011.

TEIMOURI YANSARI, A.; VALIZADEH, R.; NASERIAN, A.; CHRISTENSEN, D. A.; YU, P.; SHAHROODI, F. Effects of alfalfa particle size and specific gravity on chewing activity, digestibility, and performance of Holstein dairy cows. Journal of Dairy Science. South Oak, v. 87, p. 3912-3924, nov. 2004.

THOM, E. C. Cooling degree-days. Air Cond Heating Ventil, p. 55-65. 1958.

VAN SOEST, P. J. Nutritional ecology of the ruminant. New York: Cornell University Press, 1994. 476 p. WEST, J. W. Effects of Heat-Stress on Production in Dairy Cattle. Journal of Dairy Science. South Oak, v. 86, n. 6, jun, 2003.

YOKOYAMA, M. T.; JOHNSON, K. A. Microbiology of the rumen and intestine. In: CHURCH, D.C. THE RUMINANT ANIMAL. DIGESTIVE PHYSIOLOGY AND NUTRITION. New York: John Wiley \& Sons, 1993. p. 125-144.

YOUNG, B. A. Physiological responses and adaptations of cattle, In: YOUSEF, M. K. Stress physiology in livestock, ungulates. Florida: Baco Raton, 1985. p. 101-109. 